\title{
IMPLEMENTASI FUZZY LOGIC PADA ROBOT LINE FOLLOWER
}

\author{
Agusma Wajiansyah ${ }^{1}$, Arief Bramanto W.P², Supriadi ${ }^{3}$, Syarifah Nur ${ }^{4}$ \\ Program Studi Teknik Komputer, Jurusan Teknologi Informasi Politeknik Negeri Samarinda \\ Email: ${ }^{1}$ agusma.wajiansyah@gmail.com, ${ }^{2}$ ariefbram@gmail.com, ${ }^{3}$ supriadi.polnes@ gmail.com, \\ ${ }^{4}$ syarifahnur12@gmail.com
}

(Naskah masuk: 05 April 2018, diterima untuk diterbitkan: 28 Agustus 2018)

\begin{abstract}
Abstrak
Pada penelitian ini, akan diterapkan konsep fuzzy logic sebagai kendali cerdas pada robot line follower. Aturan pada fuzzy logic menggunakan metode mamdani. Sebagai input kendali digunakan 2 nilai hasil pembacaan sensor garis dalam bentuk data biner 6-bit. Input tersebut adalah pembacaan pada saat sampling ke- $(k)$ dan pembacaan pada saat sampling ke-(k-1). Hasil pembacaan sensor diberi bobot dengan range nilai dari 0 s/d 255 yang merupakan semesta pembicaraan dari fuzzy set input ini. Setiap fuzzy set input menggunakan 5 membershif function, dan rule base yang digunakan sebanyak 25. Pada fuzzy set output digunakan 5 membership function dengan semesta pembicaraan adalah $-127 \mathrm{~s} / \mathrm{d}+127$. output fuzzy merupakan bilangan crips tunggal yang didapat dengan menggunakan metode COG (Center of Gravity). Nilai crips output ini digunakan sebagai nilai deviasi untuk mengatur nilai PWM pada motor penggerak roda kiri dan kanan dari robot line follower. Pengujian fungsi kendali menggunakan metode matematis dan simulasi berbasis Simulink. Dari hasil yang didapat menjelaskan bahwa robot dapat bergerak mengikuti garis pandu sesuai dengan rule base yang digunakan.
\end{abstract}

Kata kunci: Kendali Cerdas, Fuzzy Logic, Mamdani, Robot Line Follower

\section{Abstract}

In this research, the fuzzy logic concept will be applied as intelligent control on line-follower robot. The rules on fuzzy logic use the Mamdani method. As control inputs, used 2 values of line sensor readings are in the form of 6bit binary data. the input is the sensor reading at the time of the kth sampling and the reading at the $k$-sampling moment. The sensor readings are weighted with a range of values from $0 \mathrm{~s} / d 255$ which is the universe of speech from the fuzzy set of these inputs. Each fuzzy set of inputs uses 5 membership function, and the base rule used is 25. In fuzzy set output used 5 membership functions with the universe of talk is $-127 \mathrm{~s} / d+127$. the fuzzy output is a single crips number obtained by using the COG (Center of Gravity) method. This output crips value is used as the deviation value to set the PWM value on the left and right wheel drive motor of the line follower robot. Tests of control functions using mathematical methods and Simulink based simulations. From the results obtained to explain that the robot can move in accordance with the design of the base rule used.

Keyword: Intelligent Control, Fuzzy Logic, Mamdani, Robot Line Follower

\section{PENDAHULUAN}

Perkembangan robotika terus mengalami kemajuan yang sangat pesat. Hal ini seiring dengan berkembangnnya teknologi embedded system. Selain itu peran serta negara dalam menyediakan wadah untuk menunjukan kreatifitas juga merupakan factor penentu dari kemajuan tersebut. Termasuk Indonesia dalam hal ini terlihat dengan diselenggarakannya Kontes Robot Indonesia. Robot Line Follower umumnya dijadikan ajang kompetisi lokal bagi institusi pendidikan untuk menyaring mahasiswa yang akan diikutkan dalam Kontes Robot Indonesia.

Line Follower Robot (LFR) adalah suatu jenis robot yang memiliki sensor untuk mendeteksi suatu garis dengan pola tertentu kemudian bergerak mengikuti garis tersebut. LFR kerap dijadikan ajang kompetisi untuk para pelajar atau mahasiswa yang baru pertama kali mempelajari bidang robotika. Berbagai metode dapat digunakan untuk menggendalikan LFR, dari metode yang sederhana yaitu if-then-rule, lookup-table. Metode PID juga banyak diterapkan pada LFR salah satunya adalah oleh Amir F (Amir, F.,F, 2014). Selain sebagai ajang kompetisi LFR juga dapat dimanfaatkan diberbagai macam bidang seperti yang dilakukan oleh Deepak P (Punetha, D., Kumar, N., Mehta, V., 2013)

Kendali cerdas pada robot memiliki tujuan agar robot dapat berpikir atau bertindak layaknya seperti manusia atau binatang. Berbagai metode dapat digunakan untuk menghasilkan kendali cerdas pada robot, salah satunya adalah Fuzzy Logic (FL). Penggunaan FL sebagai kendali juga dapat diterapkan pada applikasi selain robot, seperti pada penelitian (Edwar,2009) (Andry \& Bambang,2008). Sedangkan 
pada penelitian (Supriadi\& Wajiansyah, 2014) FL diterapkan pada perangkat embedded-sistem. Kendali cerdas berbasis FL pada sistem kendali dikenal juga dengan sebutan Fuzzy Logic Controller (FLC), dengan menggunakan metode ini proses pada sistem kendali dapat dibangun lebih mudah dan fleksibel untuk menangani sistem-sistem yang rumit tanpa memerlukan model matematis.

Pada penelitian ini akan diimplementasikan konsep FL sebagai kecerdasan pada LFR. Kendali cerdas berbasis FL ini akan mengatur pergerakan robot agar sesuai dengan referensi yang ditetapkan berdasarkan pengetahuan yang telah ditanamkan pada LFR. Selain itu pada penelitian ini diasumsikan untuk membaca garis digunakan sensor garis berbasis LED Bright dan Photo-diode yang disusun secara horizontal dengan jumlah 6 buah. Sebagai pengerak robot digunakan robot beroda dengan konfigurasi differential-drive ditambah satu roda bebas berupa ball-caster. Masing - masing roda digerakan oleh motor DC, yang memiliki pengatur kecepatan putar berbasis Pulse Width Modulation..

\section{ROBOT LINE FOLLOWER}

Robot adalah suatu benda dengan kemampuan bergerak atau bekerja secara otomatis yang dibangun dari gabungan beberapa sistem elektronika dan sistem mekanik. Mobile robot merupakan salah satu jenis robot yang memiliki kemampuan untuk berpindah posisi dengan sumber daya yang dimiliki. Robot beroda adalah contoh mobile robot yang menggunakan roda untuk berpindah posisi. Berbagai macam fungsi dapat diterapkan pada robot beroda, salah satunya adalah Line follower Robot. Konfigurasi roda dapat disesuaikan dengan kebutuhan. Salah satu contohnya adalah kofigurasi differential-drive

Proses pergerakan robot dengan konfigurasi differential-drive dikontrol oleh dua buah roda pada kedua sisinya dan satu buah roda penyeimbang. Kedua roda masing - masing terhubung pada motor yang kendalikan putarannya. Arah pergerakan robot dipengaruhi oleh kecepatan putaran roda dan arah putaran roda. Kombinasi dari berbagai kecepatan putar dan arah putaran roda akan menghasilkan prilaku berupa gerakan robot.

Pada LFR digunakan sensor untuk membaca posisi robot terhadap line-guide. Hasil pembacaan sensor berupa pola digunakan untuk menentukan prikalu yang harus dilakukan untuk mencapai referensi yang diinginkan. Proses ini ditunjukan pada gambar 1

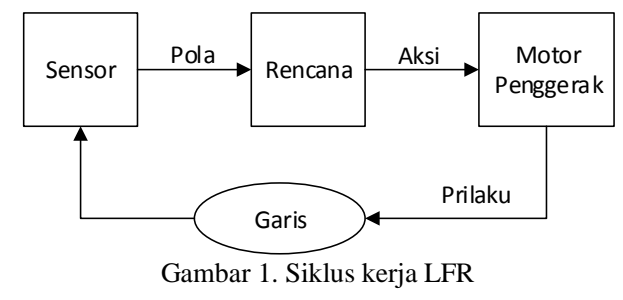

\section{KENDALI CERDAS BERBASIS FUZZY LOGIC}

FL pertama kali diperkenalkan oleh Prof. Lotfy A. Zadeh dari Universitas California diBarkeley (1965). Berbeda dengan logika boolean yang hanya membagi suatu keadaan menjadi dua kondisi yaitu 0 dan 1, FL memberikan kemungkinan suatu keadaan dalam interval antara 0 dan 1 . ilustrasi perbedaan antara logika boolean dan FL ditunjukan pada Gambar 2.
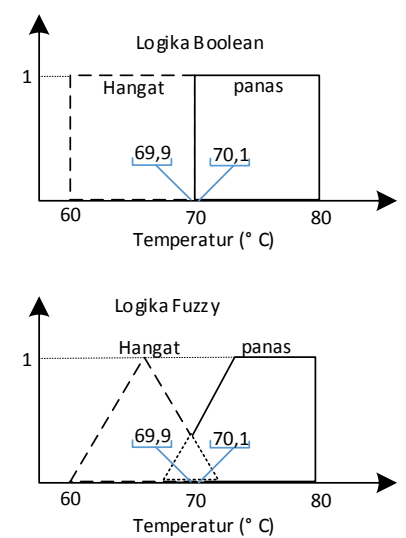

Gambar 2. Perbedaan antara Boolean Logic dan Fuzzy Logic

Dalam logika boolean, temperatur $69,9^{\circ} \mathrm{C}$ dikategorikan sebagai Hangat, dan $70,1^{\circ} \mathrm{C}$ dikategorikan sebagai Panas. Perbedaan yang kecil ini akan menimbulkan reaksi yang berarti terhadap sistem. Sementara dengan FL temperatur $69,9^{\circ} \mathrm{C}$ dan $70,1^{\circ} \mathrm{C}$ masuk dalam kategori yang sama sebagai Hangat sekaligus Panas, perbedaannya adalah derajat kepastian (memiliki nilai interval 0...1) yang dimiliki kedua suhu tersebut berbeda pada kategori 'hangat' dan 'panas'. Dan hal ini dapat dianggap dalam temperatur yang sama, sehingga tidak akan menimbulkan reaksi yang berarti bagi sistem.

\section{DESAIN SISTEM KENDALI BERBASIS FUZZY}

Untuk menerapkan FL sebagai kendali, digunakan beberapa tahapan yang terdiri dari beberapa proses yaitu Fuzzyfication, Rule Evaluation (Rule-Base \& Inferensi Fuzzy) dan Defuzzyfication. 


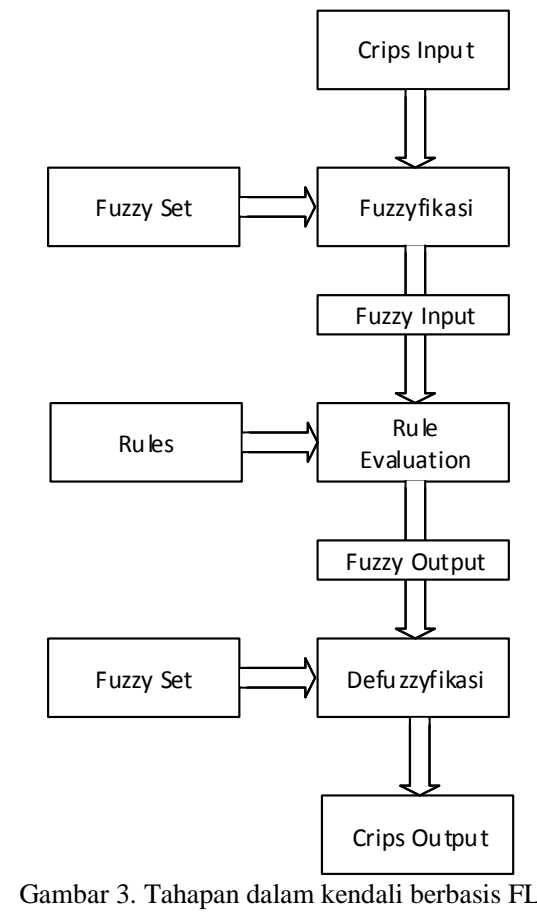

Gambar 3 menunjukkan tiga tahap tersebut lengkap dengan parameter-parameter yang diperlukan dalam setiap tahapannya. Tahap Fuzzification bertujuan untuk memproses crisp input (disebut juga Liguistic Variabel) menjadi Fuzzy input dalam bentuk linguistic value pada fuzzy Set. Fuzzy Set adalah kumpulan linguistic value yang melingkupi semesta pembicaraan dari Lingustic Variabel. Linguistic value merupakan membership function yang dapat berbentuk fungsi trapezoidal, triangular atau gaussian. Gambar 4 memperlihatkan membership function Triagular. pada proses fuzzyfication bertujuan untuk memetakan semesta pembicaraan $x$ kedalam interval $[0,1]$ dengan persamaan (1).

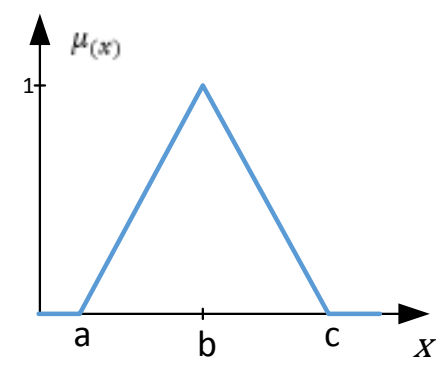

Gambar 4. Triangular membership function

$$
\mu_{(x, a, b, c)}= \begin{cases}0 & x \leq a, x \geq c \\ \frac{x-a}{b-a} & a<x \leq b \\ \frac{c-x}{c-b} & b \leq x<c\end{cases}
$$

Pada persamaan (1) dimana $a$ adalah nilai minimum fungsi, $b$ adalah nilai tengah fungsi, $c$ adalah nilai maksimum fungsi, $x$ adalah crips input, dan $\mu$ adalah derajat keanggotaan.
Pada bidang kendali Crips input merupakan bilangan tegas yang umumnya didapat dari lingkungan melalui perangkat sensor. misalnya crisp suhu $27^{\circ} \mathrm{C}$ akan ditransformasikan sebagai membership function "hangat", kecepatan 100 $\mathrm{Km} / \mathrm{jam}$ ditransformasikan sebagai membership function "cepat", dsb. Didalam Fuzzification terdapat proses Subset dengan persamaan membership function yang digunakan.

Tahap berikutnya Rule Evaluation, akan dilakukan proses penerapan fuzzy input terhadap rule base yang merupakan representasi pengetahuan yang digunakan dalam bentuk logika 'IF-THEN'. Untuk menentukan jumlah Rule Base yang digunakan, dapat digunakan persamaan sebagai berikut :

nRule $=Z^{v}$

pada persamaan (2) dimana : $Z$ dinyatakan sebagai jumlah Linguistic Value, dan $v$ dinyatakan sebagai jumlah Linguistic Variable.

Operasi Fuzzy Input pada setiap rule yang digunakan akan menghasilkan implikasi tertentu yang selanjutnya akan dilakukan proses agregasi untuk mendapatkan fuzzy output.

Tahapan terakhir adalah defuzzification. Dalam defuzzifikasi, Fuzzy output yang didapat dari proses agregasi akan diubah kembali menjadi nilai crisp. Salah satu teknik yang sering digunakan adalah metode Centre of Gravity (COG). Yang dinyatakan dalam persamaan (3)

$x_{c}=\frac{\sum_{i=1}^{n} x_{i} \mu_{x_{i}}}{\sum_{i=1}^{n} \mu_{x_{i}}}$

Pada persamaan (2) $x_{c}$ adalah nilai COG, $x_{i}$ adalah nilai $x$ pada output fuzzy hasil agregasi dan $\mu_{x_{i}}$ adalah derajat keanggotaan dari x pada output fuzzy hasil agregasi, dan $n$ adalah jumlah sampling data yang digunakan.

\section{HASIL DAN PEMBAHASAN}

\subsection{Perancangan Sistem}

Model FL yang digunakan pada penelitian ini adalah mamdani. Proses FL menggunakan 2 Liguistic Variabel sebagai Input. Input pertama didapat dari pembacaan sensor pada sampling ke $k\left(S_{k}\right)$ dan input kedua merupakan turunan dari input pertama atau nilai pembacaan sensor pada sampling ke $k-1\left(S_{k-1}\right)$. Setelah diproses melalui tahapan fuzzy berdasarkan pada rule base yang telah ditentukan, Maka diperoleh Crips Output yang digunakan sebagai nilai deviasi untuk pengaturan PWM pada motor roda kanan dan kiri. Hal ini diperlihatkan pada Gambar 5 


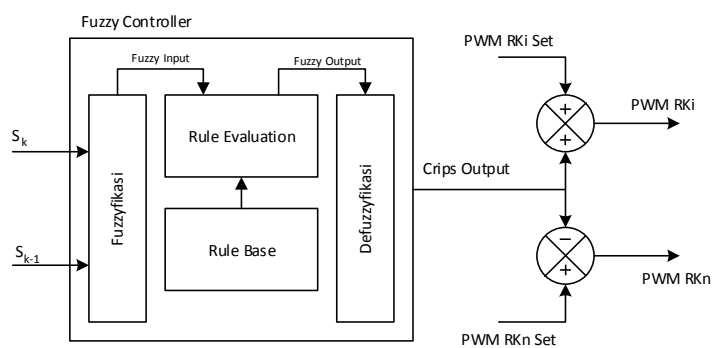

Gambar 5. Block Diagram Penerapan FL pada RLF

Crips input didapat dari sensor garis yang memberikan nilai biner 6-bit dengan nilai logika yang digunakan seperti ditunjukan pada tabel 1. Setiap logika akan dikonversi menjadi nilai unsigned interger 8-bit yang ditunjukan pada tabel yang sama, nilai ini yang akan digunakan sebagai $S_{k}$ dan $S_{k-1}$. Dari tabel tersebut tampak bahwa semakin robot mengarah kekanan maka akan memiliki bobot Crips Input yang semakin besar, dan sebaliknya. Crips Input bernilai nol menunjukan bahwa robot telah keluar dari line guide yang dapat terjadi saat robot terus bergerak kearah kanan atau terus bergerak kearah kiri. Posisi sensor terhadap line guide ditunjukan pada gambar 6
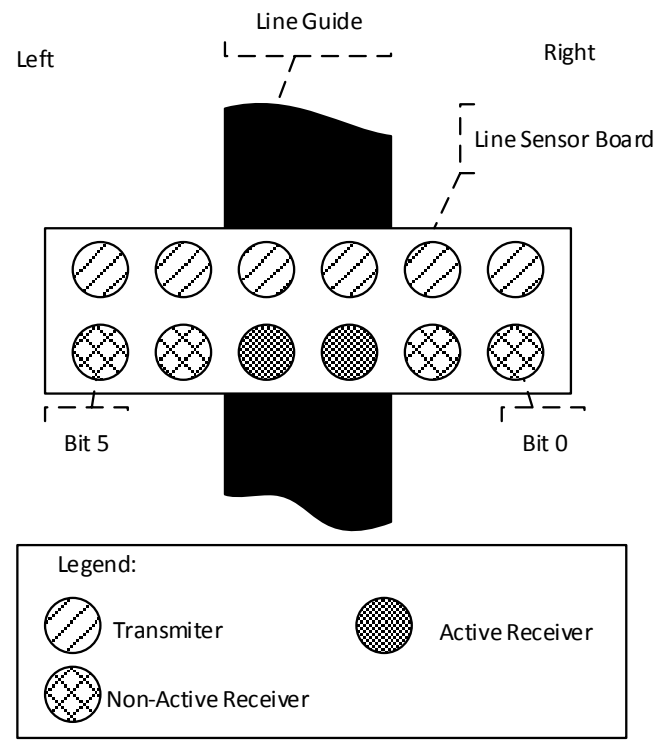

Gambar 6. Posisi sensor garis terhadap line guide

Pada gambar 7 menunjukan posisi LFR terhadap garis. Pada gambar tersebut sensor pada bit ke-5 aktif. Posisi ini diasumsikan robot condong menghadap ke kanan (Serong Kanan).

Tabel 1. Pembobotan input FLC

\begin{tabular}{|c|c|c|c|c|c|c|}
\hline \multicolumn{6}{|c|}{ Nilai Bit Sensor Garis } & \multirow{3}{*}{$\begin{array}{c}\text { Bobot Crips } \\
\text { Input }\end{array}$} \\
\hline Bit & Bit & Bit & Bit & Bit & Bit & \\
\hline 5 & 4 & 3 & 2 & 1 & 0 & \\
\hline 1 & 0 & 0 & 0 & 0 & 0 & 255 \\
\hline 1 & 1 & 0 & 0 & 0 & 0 & 227 \\
\hline 0 & 1 & 0 & 0 & 0 & 0 & 202 \\
\hline 0 & 1 & 1 & 0 & 0 & 0 & 177 \\
\hline 0 & 0 & 1 & 0 & 0 & 0 & 152 \\
\hline 0 & 0 & 1 & 1 & 0 & 0 & 127 \\
\hline 0 & 0 & 0 & 1 & 0 & 0 & 106 \\
\hline
\end{tabular}

\begin{tabular}{|c|c|c|c|c|c|c|}
\hline \multicolumn{6}{|c|}{ Nilai Bit Sensor Garis } & \multirow{3}{*}{$\begin{array}{c}\text { Bobot Crips } \\
\text { Input }\end{array}$} \\
\hline Bit & Bit & Bit & Bit & Bit & Bit & \\
\hline 5 & 4 & 3 & 2 & 1 & 0 & \\
\hline 0 & 0 & 0 & 1 & 1 & 0 & 85 \\
\hline 0 & 0 & 0 & 0 & 1 & 0 & 64 \\
\hline 0 & 0 & 0 & 0 & 1 & 1 & 42 \\
\hline 0 & 0 & 0 & 0 & 0 & 1 & 21 \\
\hline 0 & 0 & 0 & 0 & 0 & 0 & 0 \\
\hline
\end{tabular}

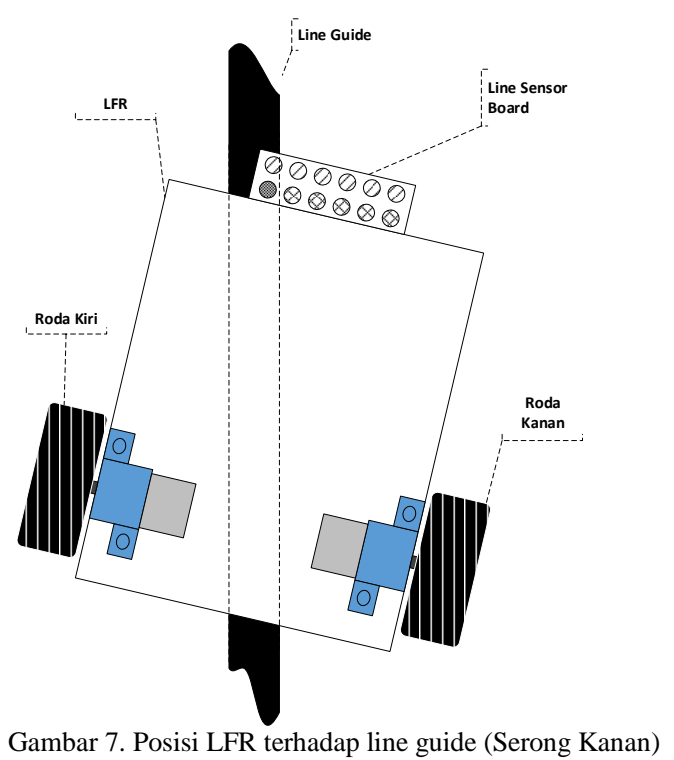

\subsection{Membangun Fuzzy Set}

Jumlah fuzzy set adalah 3 dimana dua digunakan sebagai input (proses Fuzzyfication) dan satu untuk output (proses Defuzzyfication). Gambar 8 menunjukan fuzzy set untuk input $S_{k}, S_{k-1}$ dan fuzzy set untuk output. Membership function pada semua fuzzy set menggunakan fungsi triangular. Pada fuzzy set input masing-masing terdiri dari 5 membership yaitu Serong Kiri 2 (Ki2), Serong Kiri 1 (Ki1), Center (Cnt), Serong Kanan 1 (Kn1) dan Serong Kanan2 $(\mathrm{Kn} 2)$, dengan semesta pembicaraan adalah $0 \mathrm{~s} / \mathrm{d} 255$. Sedangkan untuk output terdiri dari 5 membership yaitu Belok Kiri 2 (BKi2), Belok Kiri 1 (BKi1), Lurus, Belok Kanan 1 (BKn1) dan Belok Kanan 2 (BKn2), dengan semesta pembicaraan $-127 \mathrm{~s} / \mathrm{d}+127$.

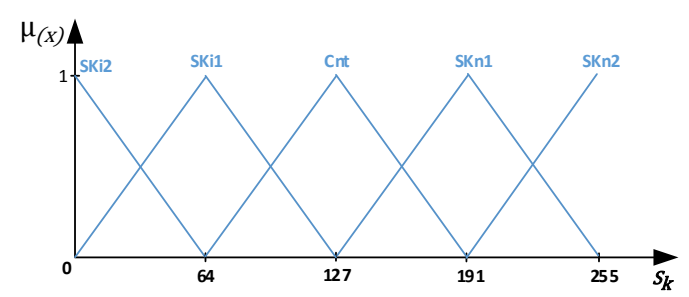



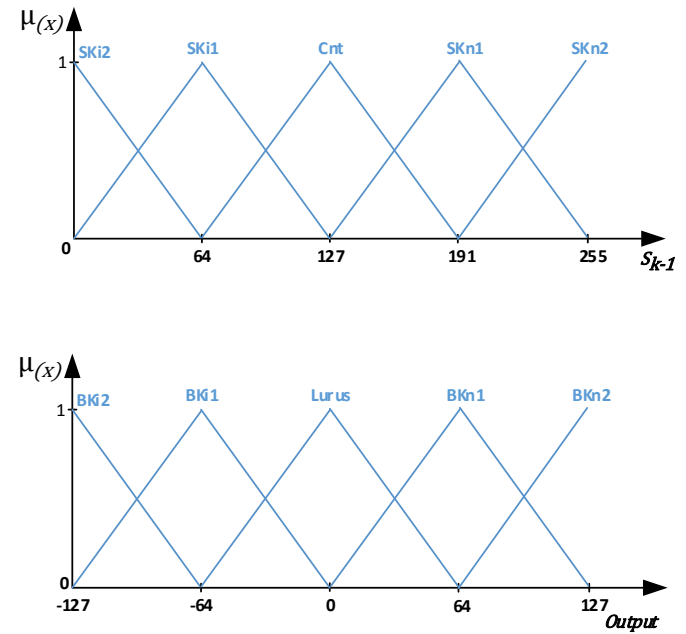

Gambar 8 Fuzzy set untuk input Sk, Sk-1 dan fuzzy set untuk output

\subsection{Membangun Rule Base}

Dengan 5 membership pada fuzzy set input dan output, maka sesuai dengan persamaan (2) jumlah rule base yang dapat dibuat maximal sebanyak 25 . rule base yang digunakan ditunjukan pada tabel 2 .

Tabel 2. Rule base FLC LFR

\begin{tabular}{|l|c|c|c|c|c|}
\hline \multicolumn{7}{|c|}{$\boldsymbol{S}_{\boldsymbol{k}}$} & \multirow{2}{*}{ SKi2 } & SKi1 & Cnt & SKn1 & SKn2 \\
\hline SKi2 & BKn2 & BKn1 & Lurus & BKi1 & BKi2 \\
\hline SKi1 & BKn2 & BKn1 & Lurus & BKi1 & BKi2 \\
\hline Cnt & BKn2 & BKn1 & Lurus & BKi1 & BKi2 \\
\hline SKn1 & BKn2 & BKn1 & Lurus & BKi1 & BKi2 \\
\hline SKn2 & BKn2 & BKn1 & Lurus & BKi1 & BKi2 \\
\hline
\end{tabular}

rule ini disusun berdasarkan hubungan antara posisi robot (yang di-capturing oleh sensor) dan gerakan (aksi) yang harus diberikan untuk membuat robot kembali pada posisi idealnya. Sebagai contoh saat robot telah pada posisi ideal, maka gerakan yang harus diberikan pada robot adalah bergerak Lurus. Sedangkan saat posisi robot berubah dari posisi ideal menjadi condong menghadap ke kanan (Serong Kanan) maka gerakan yang harus diberikan adalah berbelok ke kiri.

\subsection{Pengujian}

Pengujian dilakukan dengan dua cara yaitu secara analisis dan dengan menggunakan simulasi simulink untuk melihat respon sinyal output terhadap parameter input yang diberikan. Pada pengujian secara analisis, nilai input ditetapkan yaitu untuk $\mathrm{S}_{\mathrm{k}}=$ 152 dan $S_{k-1}=127$. Dengan nilai ini menandakan bahwa robot condong mengarah ke kanan terhadap line Guide.

Dengan nilai crips input ini akan dimasukan pada proses Fuzzification, dan dihasilkan linguistic value 'Cnt' pada fuzzy set $\mathrm{S}_{\mathrm{k}-1}$ dan linguistic value 'Cnt' dan 'SKn1' pada fuzzy set $\mathrm{S}_{\mathrm{k}}$. dengan menggunakan persamaan (1) didapat nilai derajat keanggotaan (Degree Of Membership Fuction) seperti yang ditunjukan pada gambar 9 .
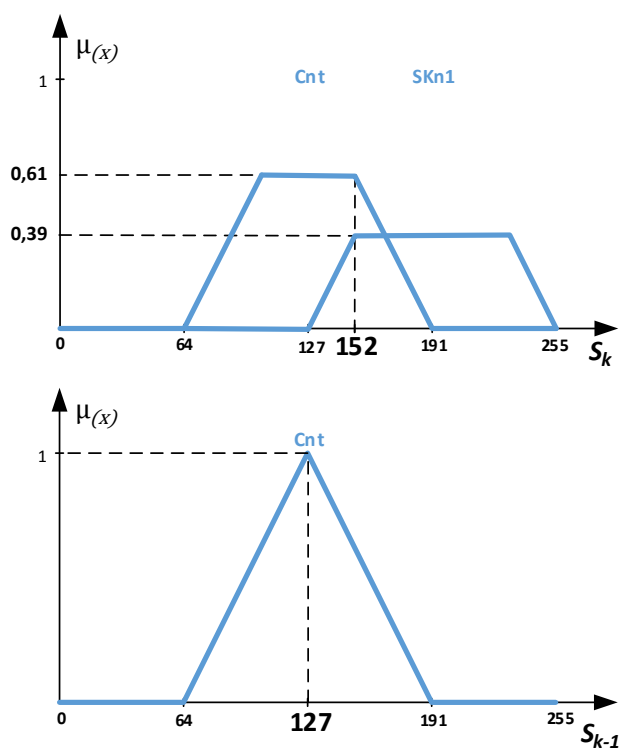

Gambar 9 Output fuzzyfikasi untuk input Sk = 152 dan Sk-1 = 127

Tahap berikutnya dilakukan operasi fuzzy pada setiap rule untuk mendapatkan implikasinya. Dengan menggunakan operator AND (min) maka rule 1 (baris 1 kolom 1 pada tabel 2) diperoleh :

IF (Sk is Ki2) AND IF(Sk-1 is Ki2) THEN (Output is BKn2)

$$
0 \text { AND } 0 \text { THEN } 0
$$

Pada rule 2 (baris 1 kolom 2 pada tabel 2) diperoleh:

IF (Sk is SKi1) AND IF(Sk-1 is SKi2) THEN (Output is BKn1)

$$
0 \text { AND } \quad 0 \quad \text { THEN } \quad 0
$$

Dan pada rule 3 dan 4 diperoleh :

$$
\begin{aligned}
& \text { IF (Sk is Cnt) AND IF(Sk-1 is SKi2) THEN (Output is Lurus) } \\
& 0,61 \text { AND } 0 \text { THEN } 0
\end{aligned}
$$

IF (Sk is SKn1) AND IF(Sk-1 is SKi2) THEN (Output is Lurus) $0,4 \quad$ AND $\quad 0 \quad$ THEN 0

Dengan cara yang sama untuk semua rule hingga didapat untuk rule ke-13 dan rule ke-14 yaitu sebagai berikut :

$$
\begin{aligned}
& \text { IF (Sk is Cnt) AND IF(Sk-1 is Cnt) THEN (Output is Lurus) }
\end{aligned}
$$

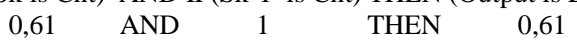

IF (Sk is SKn1) AND IF(Sk-1 is Cnt) THEN (Output is BKi1)

$$
\begin{array}{lllll}
0,4 & \text { AND } & 1 & \text { THEN } & 0,4
\end{array}
$$

Untuk setiap rule yang menghasilkan implikasi akan dilakukan proses agregasi dimana pada model mamdani digunakan operator OR (Max). Proses ini ditunjukan pada gambar 10. pada setiap membership area yang beririsan akan diambil nilai Max sebagai output proses agregasi. 

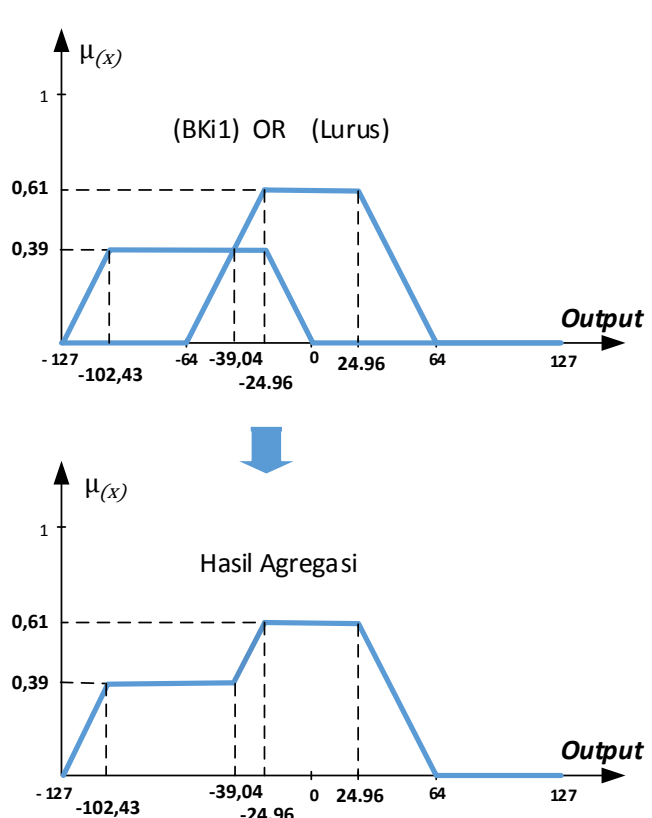

Gambar 10. Proses agregasi untuk input $\mathrm{Sk}=152$ dan $\mathrm{Sk}-1=$ 127

Hasil dari proses agregasi akan melalui proses defuzzification untuk mendapatkan nilai tunggal sebagai output FL. Persamaan (3) merupakan perhitungan COG dengan waktu diskrit. Dalam waktu kontinu, perhitungan COG mengacu pada persamaan (4).

$$
x_{c}=\frac{\int \mu_{x} \cdot x d x}{\int \mu_{x} d x}
$$

persamaan (4) merupakan penjumlahan integrasi, untuk mempermudah perhitungan output hasil agregasi dapat dibagi menjadi 5 sub-area seperti pada gambar 11 .

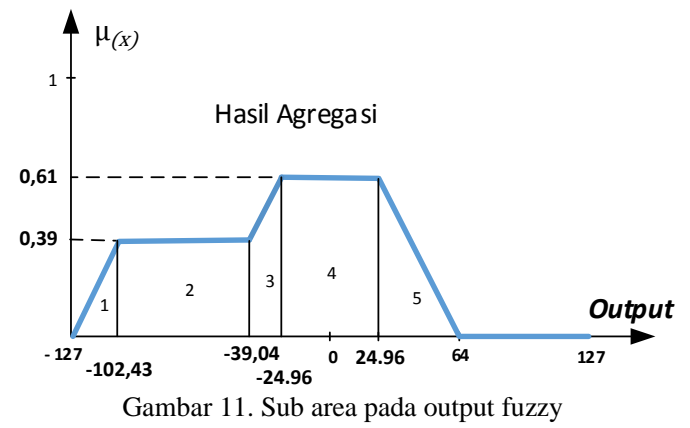

Dengan menggunakan persamaan (4), output fuzzy dapat dihitung:

$$
\begin{aligned}
& \int \mu_{x} x d x=\int_{-127}^{-102,43}\left(0.016 x^{2}+2,032 x\right) d x \\
& +\int_{-102,43}^{-39,04}(0,39 x) d x \\
& +\int_{-39,04}^{-24,96}\left(0,016 x^{2}+1,01 x\right) d x \\
& +\int_{-24,96}^{24,96}(0,61 x) d x \\
& +\int_{24,96}^{64}\left(1,01 x-0,016 x^{2}\right) d x \\
& =\left[0,0053 x^{3}+1,016 x^{2}\right]_{-127}^{-102,43} \\
& +\left[0,195 x^{2}\right]_{-102,43}^{-39,04} \\
& +\left[0,0053 x^{3}+0,505 x^{2}\right]_{-39,04}^{-24,96} \\
& +\left[0,305 x^{2}\right]_{-24,96}^{24,96} \\
& =-2090,59 \\
& +\left[0,505 x^{2}-0,0053 x^{3}\right]_{24,96}^{64} \\
& \int \mu_{x} d x=\int_{-127}^{-102,43}(0.016 x+2,032) d x \\
& +\int_{-102,43}^{-39,04}(0,39) d x \\
& +\int_{-39,04}^{-24,96}(0,016 x+1,01) d x \\
& +\int_{-24,96}^{24,96}(0,61) d x \\
& +\int_{24,96}^{64}(1,01-0,016 x) d x \\
& \int \mu_{x} d x=\left[0,008 x^{2}+2,032 x\right]_{-127}^{-102,43} \\
& +[0,39 x]_{-102,43}^{-39,04} \\
& +\left[0,008 x^{2}+1,01 x\right]_{-39,04}^{-24,96} \\
& +[0,61 x]_{-24,96}^{24,96} \\
& =78,67 \\
& +\left[1,01 x-0,008 x^{2}\right]_{24,96}^{64}
\end{aligned}
$$

Sehingga :

$$
x_{c}=\frac{\int \mu_{x} \cdot x d x}{\int \mu_{x} d x}=\frac{-2090,59}{78,67}=-26,57
$$

Dengan menggunakan tool matlab didapat hasil komputasi sebesar -26, yang ditunjukan pada gambar 12.

Dengan mengacu pada blok system pada gambar 5, jika PWM RKi Set dan PWM RKa Set sebesar 128 maka sinyal PWM yang akan diberikan ke pengerak Roda kiri (PWM RKi) dan Roda kanan (PWM RKa) adalah masing - masing 100,24 dan 155,76 dengan skala 0 sampai dengan 255. Dengan nilai PWM RKi dan PWM RKa ini maka didapat kecepatan putaran roda Kanan akan lebih cepat 
dibanding roda kiri sehingga pergerakan robot akan condong mengarah ke kiri.

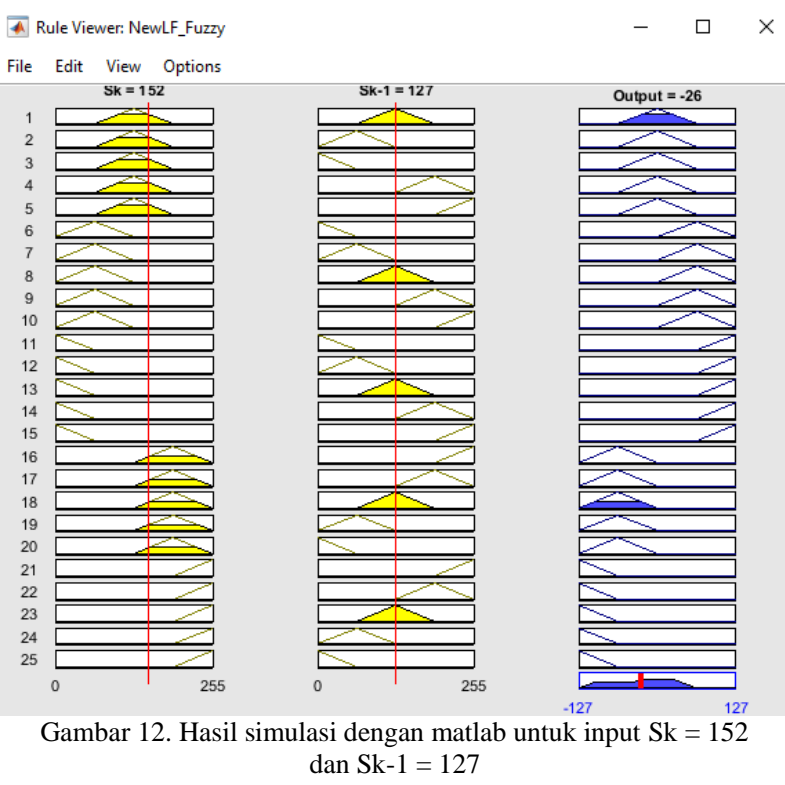

Pengujian dengan menggunakan simulink berfungsi melihat respon perubahan nilai PWM untuk motor penggerak roda Kiri dan Kanan terhadap input yang nilainya dibangkitkan secara random. kedua nilai input dibangkitkan dengan parameter nilai random yaitu minimum $=0$ maximum $=255$.

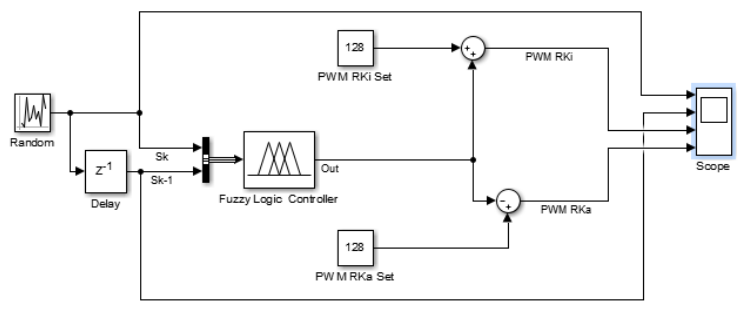

Gambar 13. Blok diagram pengujian dengan simulink

Hasil pengujian dengan durasi selama 10 detik dan sampling time sebesar 0.5 detik ditunjukan pada gambar 14.

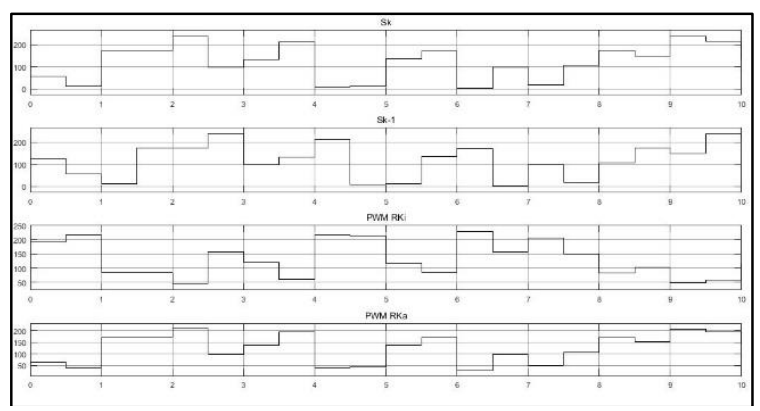

Gambar 14. Hasil pengujian dengan durasi 10 detik

Dari gambar 14 dapat diamati bahwa pergerakan robot telah sesuai dengan rule yang dibuat. Sebagai contoh saat $\mathrm{t}=4, \mathrm{Sk}=8$ dan $\mathrm{Sk}-1=212$. nilai ini berarti posisi robot condong kearah kiri (Serong ke kiri). dengan nilai tersebut dihasilkan nilai PWM untuk Roda Kiri = 217 dan PWM untuk Roda Kanan = 39. dengan nilai PWM tersebut maka robot akan bergerak ke-arah kanan.

Pengujian berikutnya dengan menerapkan FL pada model LFR yang ditunjukan pada gambar 15. pada percobaan pertama LFR diasumsikan berada pada garis lurus dengan kondisi kedua motor penggerak memiliki karakteristik yang sama. Pada percobaan kedua dengan asumsi yang sama, tetapi kedua motor penggerak memiliki karakteristik yang berbeda sehingga kecepatan angular yang dihasilkan terdapat selisih pada saat mendapat input tegangan yang sama. Hasil kedua percobaan ini ditunjukan pada gambar 16 dan gambar 17. pada percobaan kedua ini selisih kecepatan angular adalah sebesar $1 \%$.

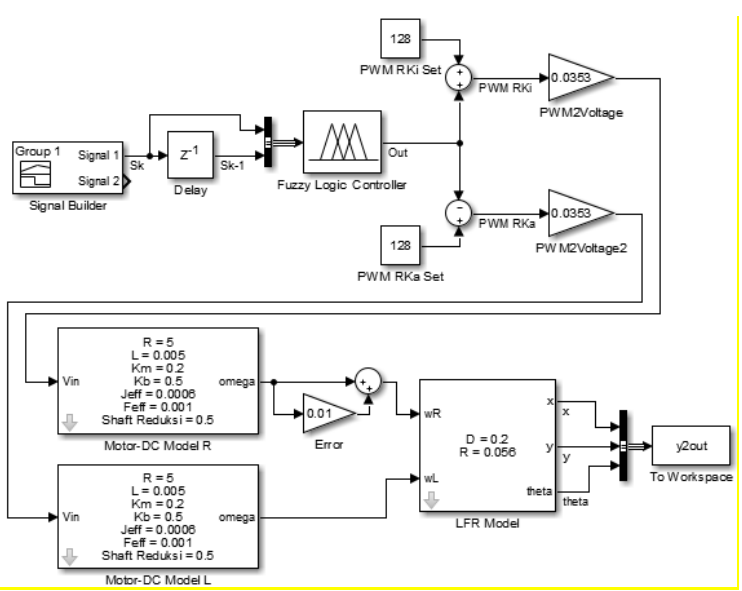

Gambar 15 Pengujian FL pada model LFR

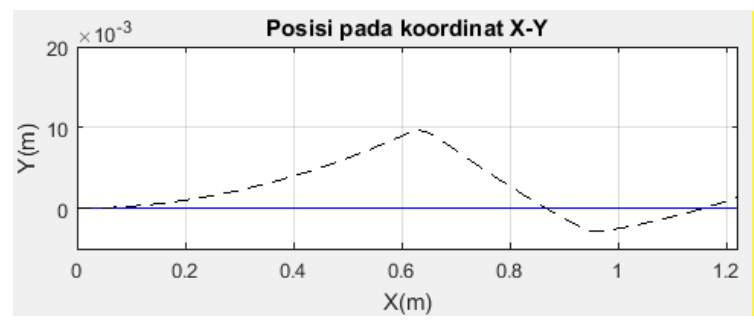

Gambar 16. Respon posisi LFR

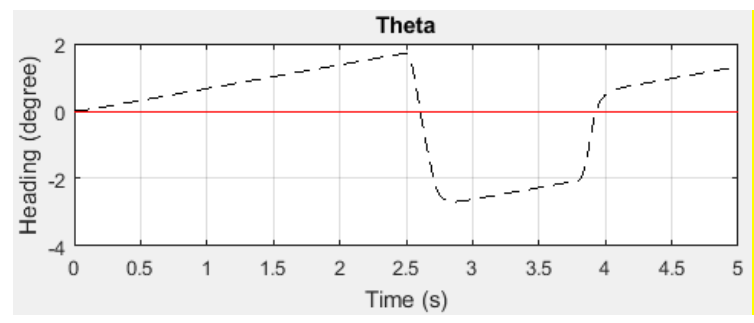

Gambar 17. Respon sudut heading LFR

Pada gambar 16, garis lurus menunjukan hasil dengan kondisi kedua motor yang ideal. Pada kondisi ini LFR dapat bergerak lurus sesuai dengan garis pandunya. Sedangkan garis putus-putus menunjukan hasil 
dengan kondisi karakteristik motor penggerak yang berbeda. Pada kondisi ini membuat LFR bergerak keluar dari garis pandu. Perubahan arah robot (heading) ini sebesar $1,7^{\circ}$ pada waktu simulasi 2,5 detik. Perubahan heading ini ditunjukan pada gambar 17, dengan garis putus-putus adalah kondisi saat karakteristik motor penggerak tidak sama. Dari kedua gambar tersebut dapat diketahui bahwa FL dapat mengembalikan posisi LFR terhadap garis pandu.

\section{PENUTUP}

Berdasarkan penelitian yang dilakukan yang mengacu pada rumusan masalah yaitu bagaimana menerapkan kendali cerdas berbasis fuzzy logic pada robot line follower, dapat ditarik beberapa kesimpulan sebagai berikut.

1. Pembentukan fuzzy set Input menggunakan pembacaan sensor garis dengan semesta pembicara 0 sampai 255 dan dibentuk 5 membership fuction, yaitu SKi2, SKi1, Cnt, SKn1, dan SKn2.

2. Pada output semesta pembicaranya -127 sampai 127, memiliki 5 membership fuction yaitu BKi1, BKi2, Lurus, BKn1 dan BKn2.

3. Berdasarkan hasil perhitungan dan simulasi metode FL dapat digunakan untuk kendali pada robot Line Follower.

Selanjutnya, dari penelitian ini akan dilakukan implementasi menjadi purwarupa, dan dilakukan pengukuran unjuk kerjanya terhadap real-word.

\section{DAFTAR PUSTAKA}

CHOWDHURY, N,H., KHUSHI, D., RASHID, M,M., 2017. Algorithm for Line Follower Robots to Follow Critical Paths with Minimum Number of Sensors, International Journal of Computer, Vol 24, No 1

FATCHURROHMAN ,AF., 2014. Skripsi: Robot Line Follower PID sebagai media pembelajaran aplikasi mikrokontroler di jurusan pendidikan teknik elektronika fakultas teknik Universitas Negeri Yogyakarta.

FAROOQ, U., AMAR, M., ASAD, M,U., ABBAS, G., HANIF, A., 2014. Fuzzy Logic Reasoning System for Line Following Robot, International Journal of Engineering and Technology, Vol 6, No 7

FAHMIZAL., SETYAWAN, G.,ARROFIQ, M., MAYUB, A., 2017, Logika fuzzy pada robot inverted pendulum beroda dua, Jurnal Teknologi Informasi dan Ilmu Komputer (JTIIK), Vol.4, No.4, hlm.244 - 252.
GUNAWAN, N.K dan ROUF, A., 2013. Purwarupa sistem kendali kecepatan mobil berdasarkan jarak dengan sistem inferensi fuzzy tsukamoto, IJEIS, Vol.3, No.2, pp. 117-126.

IQBAL, R.M,. DIKAIRONO, R dan SARDJONO, T.A., 2012. Implementasi sistem navigasi behaviour-based robotic dan kontroler fuzzy pada manuver robot cerdas pemadam api, Jurnal Teknik POMITS, Vol 1, No.1.

ISMAIL,A,H., ZAMAN, A,M,A., TERASHIMA, K., 2016. Fuzzy Logic Approach for Line Following Mobile Robot Using An Array Of Digital Sensor., International Journal of Application or Innovation in Engineering \& Management, Vol 5, Issue 7

PUNETHA, D., KUMAR, N., MEHTA, V., 2013. Development and Application of Line Following Robot Based Healt Care Management System., International Journal of Advanced Research in Computer Engineering \& Technology, Vol 2, Issue 8.

SETYO, A.A dan SUTOPO, B., 2008. Skripsi: Kendali kecepatan motor dc berdasarkan perubahan jarak menggunakan logika fuzi berbasis mikrokontroler AT89C51, Teknik Elektro, UGM.

SUPRIADI, A WAJIANSYAH., 2014. Implementasi proses Inferensi Fuzzy berbasis mikrokontroler, jurnal sains terapan teknologi informasi (Just TI ), Vol 6, No.2, pp. 687-694

TIMUR, M.B.B., GAFAR, A.F.O dan Wajiansyah, A., 2015. Desain dan Implementasi kendali cerdas untuk robot quadpod (berkaki empat) studi kasus robot pemadam api(RPA). Jurnal Teknologi Terpadu, Vol 5, No.2, pp. 140-145

YAJID,E., 2009. Penerapan Kendali Cerdas pada Sistem Tangki Air Menggunakan Logika Fuzzy., Jurnal Fisika Himpunan Fisika Indonesia, Vol 9, No.2 